\title{
How important are starvation periods in early larval development for survival of Crangon septemspinosa larvae?
}

\author{
Ingo S. Wehrtmann \\ Universidad Austral de Chile, Instituto de Zoología 'Ernst F. Kilian', Casilla 567, Valdivia, Chile
}

\begin{abstract}
Laboratory experiments on newly hatched larvae of the sand shrimp Crangon septemspinosa were conducted to study larval vulnerability to food deprivation. Larvae subjected to 6 different feeding regimes were well adapted to temporary lack of food, dependent on time and duration of starvation periods. Critical periods for larval development were the first $24 \mathrm{~h}$ after hatching, stage III and, to a lesser extent, metamorphosis. Food deprivation during the first $7 \mathrm{~d}$ resulted in a prolongation of stage I and more so stage II. After this period, larvae in the starvation treatments tended to reduce the duration of subsequent larval stages. Number of molts prior to metamorphosis ranged from 4 to 7 and were fewest in larvae fed every day. A majority (57.9\%) of the larvae reached the juvenile stage after 5 molts. Neither the duration of larval development nor the size of the juveniles obtained from the various treatments showed significant differences. The possible importance of starvation as a recruitment regulatory process for $C$. septemspinosa is discussed in terms of food availability during the major hatching period in Chesapeake Bay and adjacent waters.
\end{abstract}

\section{INTRODUCTION}

Large annual fluctuations in commercial fishery landings have been well documented for many marine species including crustaceans (for recent reviews on marine invertebrate fishery management see e.g. Caddy 1989). Although recruitment regulatory processes are not yet fully understood, variable growth and mortality in the larval phase influences recruitment success for most marine species with planktivorous larvae. Key factors for larval survival are predation, starvation or limited food resources, and oceanographic conditions that may advect larvae into unfavorable environments. However, 2 determinants of early life mortality - starvation and predation - are closely linked by growth and development processes (Bailey \& Houde 1989).

Crustacean larvae are highly sensitive to starvation (for review see Olson \& Olson 1989), and effects of food deprivation on decapod larvae have been studied in a number of species (for review see McConaugha 1985). In general, lack of suitable food in the early development of planktotrophic decapod larvae increases mortality, prolongs duration of larval development (e.g. Anger \& Dawirs 1981, Anger et al. 1981, Dawirs 1984),

(C) Inter-Research/Printed in Germany and reduces the ability of the larvae to successfully capture prey (Paul \& Paul 1980). In addition, food deprivation alters the ultrastructure of the hepatopancreas; this may result in an irreversible change of its original structure and consequently in a loss of the capability to absorb and store lipids in the hepatopancreas (Storch \& Anger 1983, Anger et al. 1985). The interaction between starvation periods and molt cycle in zoea I larvae has been investigated in a variety of decapod larvae (Anger 1987). Starvation periods also influence morphogenesis (McConaugha 1985), e.g. the thickness of the epidermis (Anger 1984), phototactic responses and swimming behavior (Cronin \& Forward 1980, Shirley \& Shirley 1988), as well as respiration and biomass of decapod larvae (Dawirs 1983, Anger 1986). However, it should be stressed that the overwhelming majority of the above-mentioned studies were carried out with brachyuran larvae, and little is known about the vulnerability of caridean larvae to food deprivation.

The sand shrimp Crangon septemspinosa plays an important role in food energy transfer in tidal marshestuarine ecosystems such as the Chesapeake Bay (Price 1962, Haefner 1979, Modlin 1980). Larvae can be found year-round in the plankton of the Chesapeake Bay and adjacent waters, with maximum production 
between January and June (Sandifer 1973, Wehrtmann 1990). The winter hatching period generally coincides with times of reduced total biomass (see Baird \& Ulanowicz 1989). Consequently, it is possible that larvae encounter starvation periods shortly after hatching. In contrast to other Crangonidae such as C. crangon and C. allmanni (Dalley 1980, Gurney 1982, Criales \& Anger 1986), larval development in C. septemspinosa under controlled conditions in the laboratory is poorly documented (Tesmer \& Broad 1964). The purpose of the study was to evaluate the effects and significance of food deprivation on development in the early larval phase of C. septemspinosa.

\section{MATERIAL AND METHODS}

Ovigerous females of Crangon septemspinosa were dredged between January and March 1989 in the lower Chesapeake Bay, USA, in standardized 1 min dredge tows using a commercial crab dredge, $1.83 \mathrm{~m}$ at the mouth, with a wire mesh lining of $12.5 \mathrm{~mm}$ on the side. The shrimps were brought to the Chesapeake Biological Laboratory in Solomons, Maryland (USA), and kept in a flow-through seawater tank until the embryos were in an advanced developmental stage. Then, females were transferred to an aerated $5 \mathrm{l}$ aquarium (15 to $18^{\circ} \mathrm{C}$ and ca $20 \%$ ) and starved until larvae hatched.

Larvae were reared individually in $20 \mathrm{ml}$ glass vials with filtered seawater $(1 \mu \mathrm{m})$ at constant temperature $\left(18^{\circ} \mathrm{C}\right)$, salinity $(20 \%)$, and a $12: 12 \mathrm{~L}: \mathrm{D}$ photoperiod. Larvae were fed on a mixture of newly hatched Artemia sp. (ca 10 nauplii $\mathrm{ml}^{-1}$ ) and Brachionus plicatilis (ca $100 \mathrm{ml}^{-1}$ ) cultured on Chlorella sp. The experiments were checked every 22 to $24 \mathrm{~h}$ for surviving larvae and exuviae; larvae were considered dead when opaque and/or when no movements of any external or internal structure could be detected. Larvae were transferred to a clean vial with filtered seawater and then fed according to the daily feeding schedule.
Larvae to be switched from a feeding to a starvation regime were washed in filtered seawater before being placed into a new vial to avoid accidental transfer of food organisms.

Based on the assumption that continuous absence of food (longer than 2 consecutive days) is not likely to occur in an estuarine environment such as the waters adjacent to the Chesapeake Bay (see Baird \& Ulanowicz 1989), 6 different feeding regimes were tested (Fig. 1). Larvae in the 'Control' were fed every day while larvae in the 'Starvation Control' were starved during the whole experiment. The number of days of starvation within the other treatments during the initial $7 \mathrm{~d}$ (indicated by the number in the treatment label) varied from 2 ('Nofood $2 d^{\prime}$ ) to $5 \mathrm{~d}$ ('Nofood $5 \mathrm{~d}$ '). Except for the Starvation Control, all larvae were fed the same after Day 7. Larvae for the Control, Nofood 3d, Nofood 2d and Nofood 5d hatched on 19 January 1989 from a single female, and larvae for the Starvation Control and Nofood $4 \mathrm{~d}$ originated from one batch each on 22 January and 15 March 1989, respectively. Each treatment originally contained 50 newly hatched larvae, and experiments were terminated when all larvae metamorphosed or died. Juvenile size was measured from the tip of the rostrum to the end of the telson using an ocular micrometer in a stereomicroscope.

Mean values for development time are given as arithmetic means and standard error and $95 \%$ confidence interval. Differences between mean values were tested by means of Student's $t$ statistics and considered statistically significant when $\mathrm{p} \leq 0.05$.

To compare survival rates within the different feeding conditions and larval stages, 50 larvae in each treatment were randomly split into 5 groups and statistically treated as replicates. After arcsine transformation (Sokal \& Rohlf 1987) percent survival in replicate groups was analyzed by ANOVA. Scheffe multiple range tests (Lehmann 1986) on $95 \%$ confidence intervals were applied to analyze the means. Those values were re-transformed to percentages.

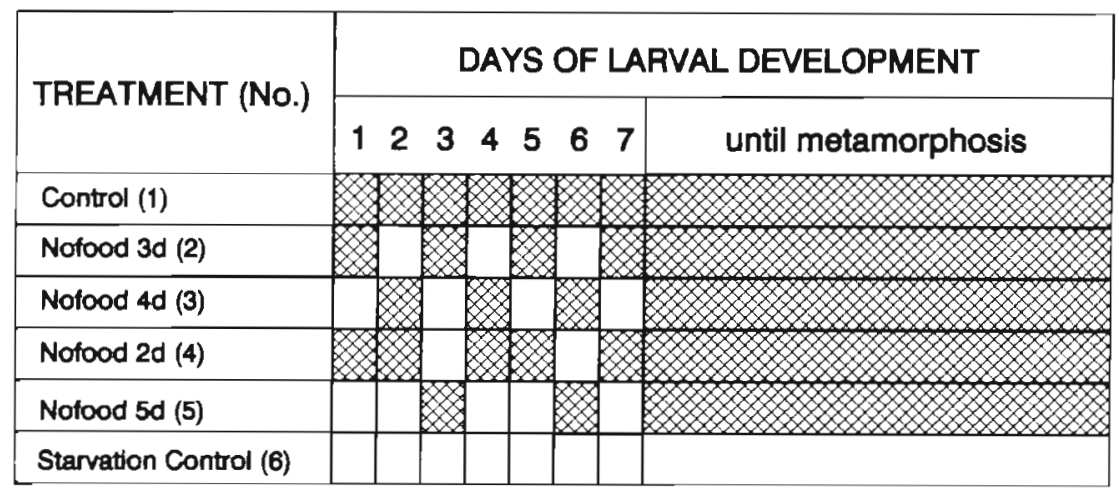

Feeding
Starvation
Fig. 1. Feeding regimes for Crangon septemspinosa larvae within the 6 different treatments. The number in the treatment labels indicates the number of starvation days; for further explanation see 'Material \& Methods' 


\section{RESULTS}

\section{General survival}

Most larvae (85.7\%) survived either stage I $(39.7 \%)$ or stage II $(60.3 \%)$ by Day 5 , and no statistically significant differences $(p>0.05)$ in survival rates for the first $5 \mathrm{~d}$ were detected among the treatments (Fig. 2). Thereafter, a sharp decline in survival was observed in Nofood 4d, Nofood 5d, and Starvation Control (Fig. 2). At the end of the experiment, survival rates in Nofood $4 \mathrm{~d}$, Nofood 5d and Starvation Control were significantly less (Scheffe grouping B, Table 1) than in the other food level groups (Scheffe grouping A, Table 1).

\section{Complete larval development}

Completion of larval development was greatest in the Control $(44 \%)$, followed by Nofood $3 \mathrm{~d}(38 \%)$ and Nofood 2d (28\%). In Nofood 5d, 2 larvae molted successfully to the second stage, and 1 larva metamorphosed after $23 \mathrm{~d}$. In the Starvation Control 2 larvae reached stage $\mathrm{II}_{\text {; }}$ however, all were dead by Day 7 .

The number of larval stages prior to metamorphosis varied between 4 and 7 with the feeding regime (Table 2). Most larvae from all treatments (57.9\%) reached the juvenile stage after 5 molts. Larvae fed every day reached metamorphosis in the fewest number of molts.

The mean duration of larval development until metamorphosis in the different feeding regimes is shown in Table 3. Larval development in Nofood $4 \mathrm{~d}$ (No. 3) was significantly longer compared to the other treatments. Lack of food after 1 or $2 \mathrm{~d}$ of initial feeding (Nofood $3 \mathrm{~d}$ and Nofood $2 \mathrm{~d}$, respectively) also resulted in a prolongation of larval development; however, the differences compared to the Control (mean duration = $18.2 \mathrm{~d})$ were not statistically significant $(p>0.05)$.

Table 1. Crangon septemspinosa. Summary of survival rate statistics of larvae in 6 different feeding regimes. The same letters in the grouping by the Scheffe multiple range test indicate no significant differences $(p>0.05)$ between feeding regimes (for further details regarding the statistical procedure see 'Material \& Methods')

\begin{tabular}{|lccc|}
\hline Treatment (No.) & $\begin{array}{c}\text { Mean } \\
\text { survival (\%) }\end{array}$ & \pm SE & $\begin{array}{c}\text { Scheffe } \\
\text { grouping }\end{array}$ \\
\hline Control (1) & 43.6 & 0.61 & $\mathrm{~A}$ \\
Nofood 3d (2) & 35.9 & 0.07 & $\mathrm{~A}$ \\
Nofood 2d (4) & 25.2 & 0.38 & $\mathrm{~A}$ \\
Nofood 4d (3) & 3.7 & 0.62 & $\mathrm{~B}$ \\
Nofood 5d (5) & 0.4 & 0.41 & $\mathrm{~B}$ \\
Starvation Control (6) & 0.0 & 0.00 & $\mathrm{~B}$ \\
\hline
\end{tabular}

Table 2. Crangon septemspinosa. Frequency distribution of the number of stages required to reach metamorphosis by larvae. Percentages in each treatment add up to $100 \%$ representing the total number of juveniles obtained in the feeding regime; results from the Starvation Control are excluded, because all larvae died before reaching metamorphosis

\begin{tabular}{|c|c|c|c|c|c|c|c|c|}
\hline \multirow{3}{*}{$\begin{array}{l}\text { Treatment } \\
\text { (No.) }\end{array}$} & \multicolumn{8}{|c|}{ No. of stages prior to metamorphosis } \\
\hline & \multicolumn{2}{|c|}{4} & \multicolumn{2}{|c|}{5} & \multicolumn{2}{|c|}{6} & \multicolumn{2}{|c|}{7} \\
\hline & $\%$ & $\mathrm{n}$ & $\%$ & $\mathrm{n}$ & $\%$ & $\mathrm{n}$ & $\%$ & $\mathrm{n}$ \\
\hline Control (1) & 31.8 & 7 & 63.6 & 14 & 4.6 & 1 & 00.0 & 0 \\
\hline Nofood 3d (2) & 11.1 & 2 & 61.1 & 11 & 11.1 & 2 & 16.7 & 3 \\
\hline Nofood 2d (4) & 15.4 & 2 & 53.8 & 7 & 23.1 & 3 & 7.7 & 1 \\
\hline Nofood 4d (3) & 00.0 & 0 & 00.0 & 0 & 33.3 & 1 & 66.7 & 2 \\
\hline Nofood $5 d(5)$ & 00.0 & 0 & 100.0 & 1 & & & & \\
\hline
\end{tabular}

Fig. 2. Crangon septemspinosa. Percent survival of larvae within the 6 different feeding regimes during the course of the experiment. Arrows indicate commencing stages; the values base on stage-specific means of developmental time for all larvae regardless of feeding regime. Since the majority of the larvae reached metamorphosis after 5 molts, only these stages are indicated by arrows

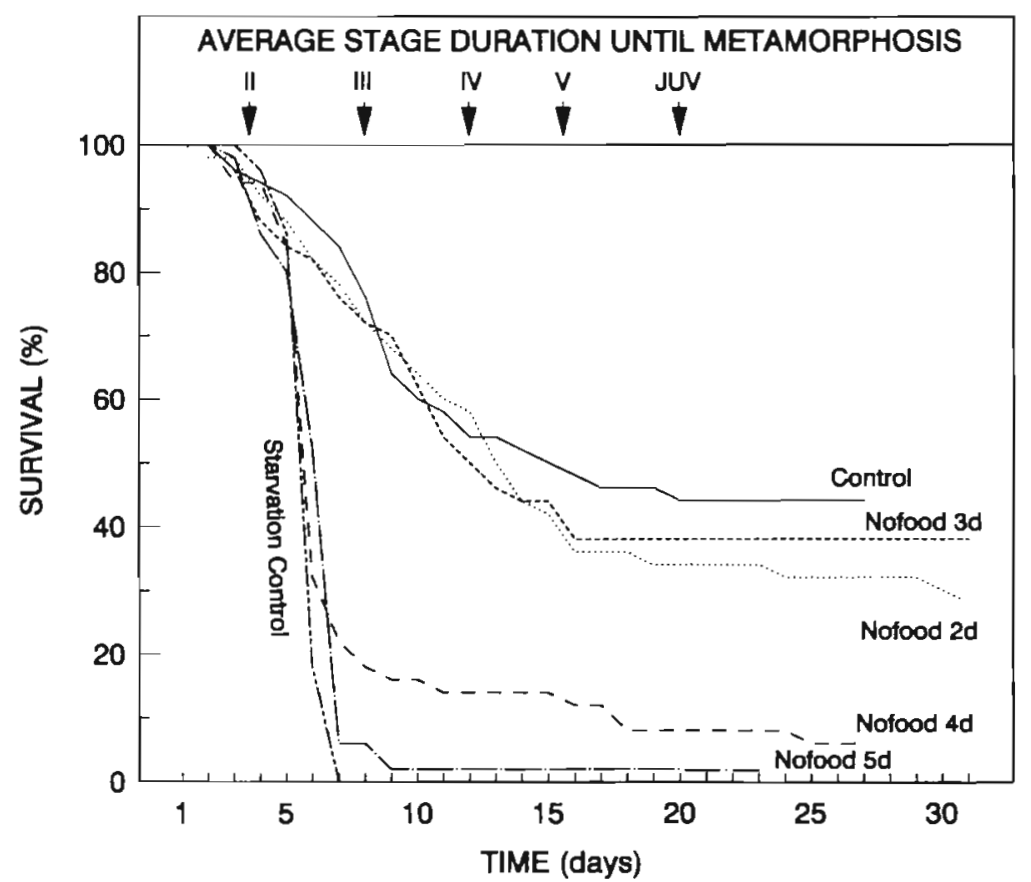




\section{Larval stage specific duration and survival}

Larval stage duration related to feeding regime is presented in Table 4. Starvation periods during the first $7 \mathrm{~d}$ mostly affected the duration of stage I and II. Lack of food during one of the first $2 \mathrm{~d}$ after hatching (Nofood 3d and Nofood 4d) caused a statistically significant $(p<0.05)$ prolongation of stage I $(3.69$ and $4.86 \mathrm{~d}$, respectively) compared to the Control (3.19 d). Any food deprivation resulted in a significant delay in development of stage II. Although not statistically significant $(\mathrm{p}>0.05)$, there was a tendency for survivors of stage II that had undergone days of starvation to shorten the duration of the subsequent larval stages compared to the Control (Table 4).

Survival within larval stages generally decreased from stage I to stage III (Table 5). Although lowest survival was observed in Nofood $2 \mathrm{~d}$, Nofood $3 \mathrm{~d}$ and Control during the third larval stage, there were no statistically significant differences in stage-specific survival ( $A$ NOVA; $p>0.05$ ) among treatments (Table 5).

\section{Size of juveniles}

Juveniles from the different feeding regimes did not differ significantly in size $(p>0.05)$. The mean size of juveniles ranged from $4.0 \mathrm{~mm}$ (Control and Nofood 5d) to $4.3 \mathrm{~mm}$ (Nofood $4 \mathrm{~d}$ ). The largest juvenile measured $5.0 \mathrm{~mm}$ (Nofood 3d) while the smallest was $3.3 \mathrm{~mm}$ (Control). The size of the juveniles increased with the number of larval stages prior to metamorphosis, although differences were not statistically significant $(\mathrm{p}>0.05)$.

\section{DISCUSSION}

This study was designed to evaluate the general vulnerability of Crangon septemspinosa larvae to star-
Table 3. Mean duration $(\bar{x})$, standard error $( \pm)$, extremes and sample size of larval development in days within the different feeding regimes; the results of the Starvation Control are excluded, because all larvae died before completion of larval development

\begin{tabular}{|lccccc|}
\hline $\begin{array}{l}\text { Treatment } \\
\text { (No.) }\end{array}$ & Mean duration & \multicolumn{2}{c|}{ Extremes } & $\begin{array}{c}\text { Sample } \\
\text { size }\end{array}$ \\
& $\bar{x}$ & \pm & Min. & Max & $\mathrm{n}$ \\
\hline Control (1) & 18.2 & 0.64 & 14 & 27 & 22 \\
Nofood 3d (2) & 21.1 & 1.10 & 16 & 31 & 18 \\
Nofood 2d (4) & 21.9 & 1.20 & 16 & 31 & 13 \\
Nofood 5d (5) & 23.0 & 0.00 & & & 1 \\
Nofood 4d (3) & 26.7 & 0.33 & 26 & 27 & 3 \\
\hline
\end{tabular}

vation and does not allow any conclusions concerning critical prey concentration or food quality. The experimental methods suffer from potentially serious artifacts, e.g. the absence of predators and unnaturally high temporal variation in food. Although the rearing methods that were applied may not have facilitated maximum growth and survival (for discussion of container effects see Swanberg et al. 1990), these culture techniques (food and container size) are commonly used in similar experiments with decapod larvae (Anger \& Dawirs 1981, Criales \& Anger 1986, Harms \& Seeger 1989). Despite the limitations of laboratory rearing experiments (see Olson \& Olson 1989), the present results do provide some indications of the potential importance of food limitation for the larval development of $C$. septemspinosa.

Feeding during the first $24 \mathrm{~h}$ after hatching is important for further survival and development. Comparing results between Nofood 3d (No. 2) and Nofood 4d (No. 3) emphasizes the importance of the initial first feeding period (Fig. 2), although larvae in these treatments were subjected to different starvation periods (3 versus $4 \mathrm{~d}$ ). These findings confirm previous observations on brachyuran larvae (e.g. Anger \& Dawirs 1981, Anger et al. 1981, Dawirs 1983, 1984, Anger 1987).

Table 4. Crangon septemspinosa. Larval stages: mean duration $(\bar{x})$, standard error ( \pm ) in days and sample size (n) within feeding regimes

\begin{tabular}{|c|c|c|c|c|c|c|c|c|c|c|c|c|c|c|c|c|c|c|}
\hline \multirow[t]{3}{*}{ Stage } & \multicolumn{18}{|c|}{ Treatment (No.) } \\
\hline & \multicolumn{3}{|c|}{$\begin{array}{l}\text { Control } \\
\text { (1) }\end{array}$} & \multicolumn{3}{|c|}{$\begin{array}{l}\text { Nofood 3d } \\
\text { (2) }\end{array}$} & \multicolumn{3}{|c|}{$\begin{array}{l}\text { Nofood } 4 \mathrm{~d} \\
\text { (3) }\end{array}$} & \multicolumn{3}{|c|}{$\begin{array}{c}\text { Nofood 3d } \\
\text { (4) }\end{array}$} & \multicolumn{3}{|c|}{$\begin{array}{c}\text { Notood } 5 d \\
(5)\end{array}$} & \multicolumn{3}{|c|}{$\begin{array}{l}\text { Starvation } \\
\text { Control }(6)\end{array}$} \\
\hline & $\bar{x}$ & \pm & $\mathrm{n}$ & $\bar{x}$ & \pm & $\mathrm{n}$ & $\bar{x}$ & \pm & $\mathrm{n}$ & $\bar{x}$ & \pm & $\mathrm{n}$ & $\bar{x}$ & \pm & $n$ & $\vec{x}$ & \pm & $\mathrm{n}$ \\
\hline I & 3.19 & 0.06 & 47 & 3.69 & 0.07 & 42 & 4.86 & 0.14 & 22 & 3.41 & 0.07 & 46 & 6.50 & 1.50 & 2 & 3.50 & 0.50 & 2 \\
\hline II & 3.74 & 0.13 & 38 & 4.72 & 0.16 & 32 & 6.71 & 0.29 & 7 & 5.13 & 0.18 & 32 & 4.00 & & 1 & & & \\
\hline III & 3.68 & 0.17 & 28 & 3.82 & 0.16 & 22 & 3.40 & 0.51 & 5 & 4.10 & 0.27 & 21 & 3.00 & & 1 & & & \\
\hline IV & 3.81 & 0.25 & 26 & 3.26 & 0.18 & 19 & 2.75 & 0.48 & 4 & 3.72 & 0.28 & 18 & 3.00 & & 1 & & & \\
\hline V & 380 & 0.20 & 15 & 3.56 & 0.18 & 16 & 3.25 & 0.25 & 4 & 4.21 & 0.28 & 14 & 4.00 & & 1 & & & \\
\hline VI & 5.00 & & 1 & 3.60 & 0.25 & 5 & 3.00 & 0.41 & 4 & 4.50 & 0.29 & 4 & & & & & & \\
\hline VII & & & & 3.67 & 0.33 & 3 & 4.00 & 0.00 & & 4.00 & & 1 & & & & & & \\
\hline
\end{tabular}


Table 5. Crangon septemspinosa. Cumulative surviva] (mean percent \pm standard error) within the first 5 larval stages for the different feeding regimes; n: number of larvae within the treatments that completed stage $V$

\begin{tabular}{|lccccccc|}
\hline \multirow{2}{*}{$\begin{array}{l}\text { Treatment } \\
\text { (No.) }\end{array}$} & \multicolumn{6}{c|}{ Mean survival within stages $(\%) \pm$ SE } & n \\
\hline Control (1) & 96.3 & 84.7 & 74.2 & 98.9 & 92.6 & 15 \\
& $(2.45)$ & $(5.61)$ & $(3.32)$ & $(4.32)$ & $(13.55)$ & \\
Nofood 3d (2) & 87.2 & 77.7 & 71.8 & 95.4 & 98.9 & 16 \\
& $(3.97)$ & $(1.70)$ & $(3.64)$ & $(7.05)$ & $(4.32)$ & \\
Nofood 4d (3) & 41.5 & 24.7 & 84.6 & 96.2 & 100 & 1 \\
& $(6.61)$ & $(11.59)$ & $(20.47)$ & $(19.49)$ & & \\
Nofood 2d (4) & 96.6 & 67.1 & 67.9 & 89.5 & 98.2 & 14 \\
& $(5.21)$ & $(0.15)$ & $(3.32)$ & $(7.60)$ & $(7.32)$ & \\
Nofood 5d (5) & 1.7 & 45.0 & 100 & 100 & 100 & 1 \\
& $(2.45)$ & $(45.00)$ & & & & \\
Starvation & 1.7 & 00.0 & & & & 0 \\
Control (6) & $(2.45)$ & & & & & \\
\hline
\end{tabular}

The importance of the initial feeding directly after hatching may partly explain the predominance of stage I decapod larvae in surface waters (e.g. Dittel \& Epifanio 1982, Lindley 1986, Wehrtmann 1986). It is likely that newly hatched larvae immediately seek food which generally is more abundant in the upper water column than in the bottom area except, perhaps, in shallow areas. Although behavioral responses of larval decapod crustaceans to light are complex and variable (Forward \& Buswell 1989), results on phototaxis and swimming behavior of early stage Rhithropanopeus harrisii larvae (Cronin \& Forward 1980) showed increased positive phototaxis with increased starvation and in some cases reduced negative phototaxis. However, the effects of starvation on phototaxis are likely to be species-specific, and behavioral responses of larval Crangon septemspinosa to light are unknown.

Other critical periods in larval development of Crangon septemspinosa are stage III and metamorphosis (Table 4). Studies on stomach and mandible development indicate a change in feeding behavior commencing with stage III (Regnault 1972). This critical period coincides also with the onset of considerable morphological variability in larval Crangon spp. (Criales \& Anger 1986). A similar pattern of reduced survival at these stages has also been documented for other crangonid (Regnault \& Costlow 1970, Regnault 1971. Criales \& Anger 1986) and palaemonid larvae (Reeve 1969, Wickins 1972a, b). For C. septemspinosa, these increased mortalities coincide with drastic changes in amino acid composition probably due to increased metabolic activities (Regnault 1971).

Larvae of Crangon septemspinosa showed relatively high survival rates during the first 4 to $6 \mathrm{~d}$ regardless of the feeding condition. A similar trend has been observed in different anomuran and brachyuran zoeae (Sulkin 1975, Anger \& Dawirs 1981, Harms \& Seeger 1989) and megalopae (Farrelly \& Sulkin 1988). However, Anger et al. (1981) detected relatively high initial mortality in brachyuran larvae subjected to food deprivation, and they related it to low viability of individual larvae. The energy reserves necessary to maintain larval metabolism are stored in the form of lipids in the hepatopancreas, mainly in the R-cells (Storch \& Anger 1983, Anger et al. 1985). Even re-feeding after a starvation period immediately after hatching cannot reestablish the ultrastructure of the R-cells (Storch \& Anger 1983). The utilization of energy reserves in the hepatopancreas cells may explain the initial high survival of $C$. septemspinosa under all feeding conditions. However, the depletion of these energy sources and the irreversible change in the ultrastructure of the Rcells may be responsible for the drastic increase in mortality within Nofood 4d, Nofood 5d, and Starvation Control (Fig. 2).

Some newly hatched larvae of Crangon septemspinosa were still able to molt despite food deprivation commencing immediately after hatching. Several studies with different species (Anger et al. 1981, Dawirs 1984, Harms \& Seeger 1989) confirm the necessity for brachyuran and anomuran larvae to feed immediately after hatching in order to start the molt cycle. The 2 molting larvae in the Starvation Control and the metamorphosis of 1 larva after an initial $2 \mathrm{~d}$ starvation period indicate that newly hatched $C$. septemspinosa larvae apparently have the potential to begin molting even without any external energy supply. This finding compares favorably with results reported for starved Palaemonetes pugio (Broad 1957) and Pandalus borealis (Stickney \& Perkins 1981) larvae. However, C. nigricauda larvae die within $4 \mathrm{~d}$ at stage $\mathrm{I}$ if no food is ingested (Villamar \& Brusca 1987). Further studies should be carried out to determine if $C$. septemspinosa larvae generally hatch with sufficient internal energy resources to molt to the second stage without an external food supply.

Starvation periods in early development increased the number of molts prior to metamorphosis (Table 2). In contrast to Lebour (1931), who proposed a 5-stage development for crangonid shrimp larvae, variability in both larval forms and pathways of larval development of different Crangon species has been well documented (Criales \& Anger 1986, Villamar \& Brusca 1988). Variations in instar number in larval Palaemonetes sp. (Broad 1957, Knowlton 1974), Palaemon serratus (Reeve 1969) and Callinectes sapidus (Sulkin 1978) have been related to diet. Criales \& Anger (1986) stated that malnutrition in C. crangon and C. allmanni is apparently a condition affecting morphogenesis; the results of the present study strongly support this. However, based on the 
present results, it should be noted that an increase in the number of larval stages before metamorphosis does not necessarily lead to a significant prolongation of the larval planktonic period (Table 3 ) or to a significant sizedifference in the resulting juveniles.

Starvation periods in early development resulted in a prolongation of stage I and II (Table 4). The lengthening of these stages can be viewed as an additional period necessary to accumulate enough reserves to molt successfully to the next instar. This interpretation is supported by studies conducted with brachyuran larvae under starvation conditions (Anger \& Dawirs 1981, Anger et al. 1981). After reaching the second instar, however, early starved larvae tended to shorten the duration of the subsequent stages (Table 4 ). Similar results were obtained for 2 species of brachyurans (Anger \& Dawirs 1981, McConaugha 1982). The underlying processes of partial compensation in development rate after an early period of unfavorable conditions are not yet understood. Therefore, further studies should focus on possible cues responsible for this ecologically important regulatory mechanism.

The prolongation of the development time of the first 2 larval stages under the effect of starvation (Table 4) may be important to the recruitment process: since the early stages of small individuals tend to be most vulnerable to predation (Bailey 1984, Morgan 1987, 1990), a lengthening of the initial planktonic phase may result in a higher cumulative mortality rate at the end of the larval period. In addition, starvation diminishes the swimming ability of decapod larvae (Cronin \& Forward 1980, Shirley \& Shirley 1988) and thus reduces the larval ability to escape and survive attacks of planktivorous predators. However, an interpretation of the results presented in Table 4 with regard to possible mortality rates in the field is critical because the larval rearing in the laboratory was conducted in the absence of predators.

Crangon septemspinosa larvae proved to be well adapted to food shortage in a 'patchy' environment produced by the study design. The findings regarding survival and developmental rate in Nofood $3 \mathrm{~d}$ clearly demonstrate that even a $24 \mathrm{~h}$ starvation period after initial feeding does not result in mass mortality. In addition, major hatching activities of $C$. septemspinosa in the Chesapeake Bay and adjacent waters take place from March to June (Sandifer 1973, Butt 1986, Wehrtmann 1990) coinciding with the spring phytoplankton bloom (Marshall 1980, Marshall \& Cohn 1983, Marshall \& Lacouture 1986) and a general rise in biological activity (Baird \& Ulanowicz 1989). Thus, larvae have the opportunity to graze at least on phytoplankton, a suitable food for Crangon larvae (Villamar \& Brusca 1987). Tidally induced phytoplankton patchiness in the estuarine environment has been documented for the
Middle Atlantic Bight (Dustan \& Pinckney 1989), and such periodic aggregations may locally improve the larval feeding conditions. Therefore, it is likely that newly hatched $C$. septemspinosa larvae may be able to encounter sufficient food to support further development. However, starvation may have significant impact on survival rates when hatching larvae are transported into offshore areas with unfavorable conditions (e.g. concerning temperature regime and food quantity).

To clarify the importance of starvation for Crangon septemspinosa larvae as a recruitment regulatory process, information regarding natural prey, spatio-temporal occurrence of these prey taxa and critical prey concentrations required for daily maintenance of the larvae are needed. Furthermore, knowledge about interactions between sand shrimp larvae and their potential predators, for example bay anchovy Anchoa mitchilli, would help to understand recruitment variability.

Acknowledgements. The study was financially supported by the Deutsche Forschungsgemeinschaft (DFG) (Aktenzeichen Ha 138/36-1). I am also grateful to the Chesapeake Biological Laboratory, University of Maryland, and especially to Dr E. D. Houde for providing working facilities. A. V Vázquez helped me in the laboratory during the course of the experiments. Special thanks are due to Drs C. E. Epifanio, E. D. Houde and C. Stagg for critically reviewing an earlier draft of the manuscript. This is contribution no. 2217 from the Center for Environmental and Estuarine Studies of the University of Maryland System.

\section{LITERATURE CITED}

Anger, K. (1984). Influence of starvation on moult cycle and morphogenesis of Hyas araneus larvae (Decapoda, Majidae). Helgoländer Meeresunters. 38: 21-33

Anger, K. (1986). Changes of respiration and biomass of spider crab (Hyas araneus) larvae during starvation. Mar Biol. 90: $261-269$

Anger, K. (1987). The $\mathrm{D}_{0}$ threshold: a critical point in the larval development of decapod crustaceans. J. exp. mar. Biol. Ecol. 108: 15-30

Anger, K., Dawirs, R. R. (1981). Influence of starvation on the larval development of Hyas araneus (Decapoda, Majidae) Helgoländer Meeresunters. 34: 287-311

Anger, K., Dawirs, R. R., Anger, V., Costlow, J. D. (1981) Effects of early starvation periods on zoeal development of brachyuran crabs. Biol. Bull. mar biol. Lab., Woods Hole 161. 199-212

Anger, K., Storch, V., Anger, V., Capuzzo, J. M. (1985). Effects of starvation on moult cycle and hepatopancreas of stage I lobster (Homarus americanus) larvae. Helgoländer Meeresunters. 39: 107-116

Bailey, K. M. (1984). Comparison of laboratory rates of predation on five species of marine fish larvae by three planktonic invertebrates: effects of larval size on vulnerability. Mar. Biol. 79: 303-309

Bailey, K. M. Houde, E. D. (1989). Predation on eggs and larvae of marine fishes and the recruitment problem. Adv. mar Biol. 5: 1-83 
Baird, D. Ulanowicz, R. E. (1989). The seasonal dynamics of the Chesapeake Bay ecosystem. Ecol. Monogr. 59 (4): 329-364

Broad, A. C. (1957). Larval development of Palaemonetes pugio Holthuis. Biol. Bull. mar. biol. Lab., Woods Hole 112 : $144-161$

Butt, A. J. (1986). Common decapod larvae of lower Chesapeake Bay and adjacent coastal waters with a key to zoea and megalopae. Appl. Mar Res. Lab., Old Dominion Univ., Norfolk, Tech. Rep.

Caddy, J.F. (1989). Marine invertebrate fisheries: their assessment and management. J. Wiley \& Sons, New York

Criales, M. M., Anger, K. (1986). Experimental studies on the larval development of the shrimps Crangon crangon and C. allmanni. Helgoländer Meeresunters. 40: 241-265

Cronin, T. W., Forward, R. B., Jr (1980). The effects of starvation on phototaxis and swimming of larvae of the crab Rhithropanopeus harrisii. Biol. Bull. mar. biol. Lab., Woods Hole 158: 283-294

Dalley, R. (1980). The survival and development of the shrimp Crangon crangon (L.), reared in the laboratory under noncircadian light-dark cycles. J. exp. mar. Biol. Ecol. 47 $101-112$

Dawirs, R. R. (1983). Respiration, energy balance and development during growth and starvation of Carcinus maenas $\mathrm{L}$. larvae (Decapoda: Portunidae). J. exp. mar. Biol. Ecol. 69 105-128

Dawirs, R. R. (1984). Influence of starvation on larval development of Carcinus maenas L. (Decapoda: Portunidae). J exp. mar. Biol. Ecol. 80: 47-66

Dittel, A. I., Epifanio, C. E. (1982). Seasonal abundance and vertical distribution of crab larvae in Delaware Bay. Estuaries 5 (3): 197-202

Dustan, P., Pinckney, J. L. (1989). Tidally induced estuarine phytoplankton patchiness. Limnol. Oceanogr. 34 (2): $410-419$

Farrelly, C., Sulkin, S. D. (1988). Effects of starvation in megalopal development in the brachyuran crab Hemigrapsus oregonensis. J. Crust. Biol. 8 (4): 614-617

Forward, R. B., Jr, Buswell, C. U. (1989). A comparative study of behavioural responses of larval decapod crustaceans to light and pressure. Mar. Behav. Physiol. 16: 43-56

Gurney, A. R. (1982). The larval development of Crangon crangon (Fabr. 1795) (Crustacea: Decapoda). Bull. Br. Mus. nat. Hist. (Zool.) 42 (4): 247-262

Haefner, P. A., Jr (1979). Comparative review of the biology of north Atlantic caridean shrimps (Crangon), with emphasis on C. septemspinosa. Bull. Biol. Soc. Wash. 3: 1-40

Harms, J., Seeger, B. (1989). Larval development and survival in seven decapod species (Crustacea) in relation to laboratory diet. J. exp. mar Biol. Ecol. 133: 129-139

Knowlton, R. E. (1974). Larval development processes and controlling factors in decapod Crustacea, with emphasis on Caridea. Thalassia Jugosl. 10 (1/2): 139-158

Lebour, M. V. (1931). The larvae of the Plymouth Caridea. - I The larvae of the Crangonidae. II. The larvae of the Hippolytidae. Proc. Zool. Soc. Lond. 1931: 1-9

Lehmann, E. L. (1986). Testing statistical hypothesis, 2nd edn. J. Wiley \& Sons, New York

Lindley, J. A. (1986). Vertical distribution of decapod crustacean larvae and pelagic post-larvae over Great Sole Bank (Celtic Sea) in June 1983. Mar. Biol. 90: 545-549

Marshall, H. G. (1980). Seasonal phytoplankton composition in the lower Chesapeake Bay and Old Plantation Creek, Cape Charles, Virginia. Estuaries 3 (3): 207-216

Marshall, H. G., Cohn, M. S. (1983). Distribution and composition of phytoplankton in northeastern coastal waters of the United States. Estuar. coast. Shelf Sci. 17: 119-131
Marshall, H. G., Lacouture, R. (1986). Seasonal patterns of growth and composition of phytoplankton in the lower Chesapeake Bay and vicinity. Estuar. coast. Shelf Sci. 23: $115-130$

McConaugha, J. R. (1982). Regulation of crustacean morphogenesis in larvae of the mud crab, Rhithropanopeus harrisii. J. exp. Zool. 223: 155-163

McConaugha, J. R. (1985). Nutrition and larval growth. In: Wenner, A. M. (ed.) Larval growth. Balkema Press, Rotterdam, p. 127-154

Modlin, R. F. (1980). The life cycle and recruitment of the Sand Shrimp, Crangon septemspinosa, in the Mystic River estuary, Connecticut. Estuaries 3 (1): 1-10

Morgan, S. G. (1987). Morphological and behavioral antipredatory adaptations of decapod larvae. Oecologia (Berl.) 73: $393-400$

Morgan, S. G. (1990). Impact of planktivorous fishes on dispersal, hatching, and morphology of estuarine crab larvae. Ecology 71 (5): 1639-1652

Olson, R. R., Olson, M. H. (1989). Food limitation of planktotrophic marine invertebrate larvae: does it control recruitment success? Ann. Rev. Ecol. Syst. 20: 225-247

Paul, A. J., Paul, J. M. (1980). The effect of early starvation on later feeding success of king crab zoeae. J. exp. mar. Biol. Ecol. 44: 247-251

Price, K. S., Jr (1962). Biology of the sand shrimp, Crangon septemspinosa, in the shore zone of the Delaware Bay region. Chesapeake Sci. 3 (4): 245-255

Reeve, M. R. (1969). Growth, metamorphosis and energy conversion in the larvae of the prawn, Palaemon serratus. J. mar. biol. Ass. U.K. 49: 77-96

Regnault, M. (1971). Acides aminés libres chez les larves de Crangon septemspinosa (Caridea). Variation de leur taux de l'éclosion à la métamorphose. Leur role au cours du développement et leur importance dans la nutrition. Mar. Biol. 11: $35-44$

Regnault, M. (1972). Développement de l'estomac chez les larves de Crangon septemspinosa Say (Crustacea, Decapoda, Crangonidae); son influence sur le mode de nutrition. Bull. Mus. Hist. nat., Paris 67 (Zool. 53): 841-856

Regnault, M., Costlow, J. D. (1970). Influence de la témperature et de la salinité sur le développement larvaire de Crangon septemspinosa Say (Decapoda, Caridea). Vie Milieu 21 (A2): 453--466

Sandifer, P. A. (1973). Distribution and abundance of decapod crustacean larvae in the York River estuary and adjacent lower Chesapeake Bay, Virginia, 1968-1969. Chesapeake Sci. 14 (4): 235-257

Shirley, S. M., Shirley, T C. (1988). Behavior of red king crab larvae: phototaxis, geotaxis and rheotaxis. Mar. Behav. Physiol. 13: 369-388

Sokal, R. R., Rohlf, F. J. (1987). Introduction to biostatistics, 2nd edn. W. H. Freeman and Co., New York

Stickney, A. P., Perkins, H. C. (1981). Observations on the food of the larvae of the northern shrimp, Pandalus borealis Kröyer (Decapoda, Caridea). Crustaceana 40 (1): 36-49

Storch, V., Anger, K. (1983). Influence of starvation and feeding on the hepatopancreas of larval Hyas araneus (Decapoda, Majidae). Helgoländer Meeresunters. 36: 67-75

Sulkin, S.D. (1975). The significance of diet in the growth and development of larvae of the blue crab, Callinectes sapidus Rathbun, under laboratory conditions. J. exp. mar. Biol. Ecol. 20: 119-135

Sulkin, S.D. (1978). Nutritional requirements during larval development of the portunid crab, Callinectes sapidus Rathbun. J. exp. mar Biol. Ecol. 34: 29-41

Swanberg, N., Båmstedt, U., Madin, L. P. (1990). Assessing the 
role of gelatinous zooplankton in the marine environment - a critique. Int. Coun. Explor. Sea Comm. Meet. ICES C.M./L: 84, Sess. V: 1-11

Tesmer, C. A., Broad, A. C. (1964). The larval development of Crangon septemspinosa (Say). Ohio J. Sci. 64 (4): 239-250

Villamar, D. F., Brusca, G. J. (1987). Survival and growth of Crangon nigricauda larvae (Decapoda, Caridea) raised on experimental diets. J. World Aquacult. Soc. 18 (1): 11-25

Villamar, D. F., Brusca, G. J. (1988). Variation in the larval development of Crangon nigricauda (Decapoda: Caridea), with notes on larval morphology and behavior. J. Crust. Biol. 8 (3): 410-419

Wehrtmann, I. S. (1986). Feld- und Laboruntersuchungen

This article was presented by K. R. Tenore, Solomons, Maryland, USA über natante Dekapodenlarven in der Deutschen Bucht. Dipl. Thesis, Univ. Hamburg

Wehrtmann, I. S. (1990). Untersuchungen zur Larvalökologie von Crangon septemspinosa Say (Decapoda, Caridea) und die Modellierung des Larventransportes. Ph.D. thesis, Univ. Hamburg

Wickins, J. F. (1972a). The food value of brine shrimp, Artemia salina L., to larvae of the prawn, Palaemon serratus Pennant. J. exp. mar. Biol. Ecol. 10: 151-170

Wickins, J. F. (1972b). Development in the laboratory culture of the common prawn, Palaemon serratus Pennant. Fish. Invest. Minist. Agric. Fish. Food (GB) Ser. II Salmon Freshwater Fish. 27 (4): 1-23

Manuscript first received: October 2, 1989

Revised version accepted: April 5, 1991 